\title{
THE INFLUENCE ANALYSIS OF HUMAN RESOURCES, CAPITAL INCOME, DEVELOPMENT EXPENDITURE BUDGET AND REAL GRDP ON HUMAN DEVELOPMENT INDEX IN MANDAILING NATAL REGENCY
}

\author{
Hamonangan Nasution1 ${ }^{*}$, Eko Wahyu Nugrahadi ${ }^{2}$ \\ ${ }^{1 *}$ Postgraduate Program, Universitas Negeri Medan \\ ${ }^{2}$ Faculty of Economics, Universitas Negeri Medan \\ Email: hamonangan@yahoo.com
}

\begin{abstract}
Quality of Human Resources in developing countries and poor countries is a very serious issue to be addressed. When the quality of human resources do not keep pace with the progress of time involved will lead to underdevelopment, poverty and unemployment which in turn trigger the overflow gap, inequality and adversity. This study aims to look at and determine how much influence Number of Qualified Persons, Budget Development, Real Gross Domestic Product and Shopping Structural Transformation of the Human Development Index in Mandailing Natal Regency. Used in measuring and analyzing time series data (time series) in the form of quarters in the period 2003 : Q1 - 2012 : Q4 . Data analysis using OLS (Ordinary Least Square) which is multiple regression. The results showed $R H Q$ variable positive and significant effect on the HDI Mandailing Natal district, $A B P$ variablespositive and significant effect on the HDI Mandailing Natal Regency, any one significant negative effect on the HDI in Mandailing Natal Regency is Shopping Structural Transformation, while variable GRDPCP positive and significant impact on HDI of Mandailing Natal Regency. in $\alpha=5 \%$. The result of the regression model of $H D I$ policy is $R$-squered $=0,8967$ whereas the presence of the model is R-squered BTS=0,8907 in Mandailing Natal Regency, after the classic test. This means that in thebase stations are very well organized affect $H D I$, whereas if done deviation will adversely affect the HDI.
\end{abstract}

Key words: Human Development Index, Number of Quality of Human Resources, Budget Development, Real GRDP and Structural Transformation Shopping

\section{INTRODUCTION}

he Quality of Human Resources (QHR) in developing countries and poor countries is a very serious problem to be handled for the sake of a country's economic growth. The reality has proven that if the quality of human resources does not keep pace with the progress of the times it will cause underdevelopment, poverty and abundant unemployment which in turn triggers inequality, inequality and downturn. The Quality of Human Resources (QHR) should research and finally create new things or it is hoped that it will reveal or explore all economic sectors that are the source of regional income. Why is it that the western world tends to be more capable of doing much in research and even creating? This indicates that in general Indonesia,

$$
\text { QE Journal | Vol.09 - No.02 - } 1
$$


especially urban districts, is weaker in doing psychomotor, because when viewed for this purpose there are many barrier factors in the regions compared to the province, for example in the teaching and learning process in elementry school, junior high school, senior high school and in Higher Education; of the three things the report card demands are complete theory, complete practice and complete attitude, in areas that are complete only a theory.

In particular, the Mandailing Natal Regency, where its natural resources are so promising, according to data from Statistics Indonesia of North Sumatera from 25 regencies in North Sumatera, Mandailing Natal has the richest natural potential, then the question is why the central government has the courage to provide the General Allocation Fund (GAF) and the Special Allocation Fund (SAF) for Madina Regency, the largest in the last 10 years, is none other than because Madina is considered one of the balance of payments assets for the state, if that is why its human resources are left so weak to work and innovate, the main indicator of weak human resources can be seen from (Todaro, Smith, 2006):

1. Unequal income, (10\% conglomerates, $30 \%$ are well-off and $60 \%$ below the poverty line).

2. Less able to meet basic consumption needs and improve the situation (according to the Association Development Bank (ADB), basic consumption per person = $2,100 \mathrm{kkl} /$ day, however $60 \%$ of Indonesia's population still consumes only 1,571 $\mathrm{kkl} / \mathrm{day}$.

3. Lack of job opportunities and places to work (SI 2012)

4. Average income per person (IPC) is still below ILO and ADB standards, namely (= $\$ 1,000.00$ USD / year $=\$ 83,333.00 /$ month $=\$ 4.00 /$ day or if the exchange rate per dollar is Rp. 8,000, - then the same as + Rp. 32,000 / day / person, equivalent to $2,500 \mathrm{kkl}$.

5. Decreasing social and moral aspects, such as the following negative attitudes in this nation:

a. Closed (conglomerates don't care about the poor)

b. Indifferent (rampant KKN)

c. Not responsive in understanding the strategic meaning of modernization and globalization

d. Less selective in responding to change

In the following table it can be seen that in 2001 to 2012 the highest value of the Human Development Index (HDI) was Medan City at $75.4 \%$ and the lowest was Nias Regency at 66.5\%. Mandailing Natal District is in the 18th (eighteenth) position with an HDI of $67.5 \%$.

Table 1: Human Development Index (HDI) by Regency / City in North Sumatera in 2012

\begin{tabular}{|c|c|c|}
\hline No. & Regency City & HDI in 2012 ( \% ) \\
\hline 1. & Medan & $\mathbf{7 5 , 4}$ \\
\hline 2. & Bijai & 74,7 \\
\hline 3. & Pematang Siantar & 74,6 \\
\hline 4. & Tebing Tinggi & 74,3 \\
\hline
\end{tabular}

QE Journal | Vol.09 - No.02 - 2 


\begin{tabular}{|c|c|c|}
\hline 5. & Tanjung Balai & 73,8 \\
\hline 6. & Karo & 73,5 \\
\hline 7. & Sibolga & 72,9 \\
\hline 8. & Langkat & 72,3 \\
\hline 9. & Deli Serdang & 71,6 \\
\hline 10. & Dairi & 71,5 \\
\hline 11. & Simalungun & 70,9 \\
\hline 12. & Asahan & 70,7 \\
\hline 13. & Labuhan Batu & 70,6 \\
\hline 14. & Toba Samosir & 70,5 \\
\hline 15. & Tapanuli Utara & 69,9 \\
\hline 16. & Tapanuli Tengah & 69,7 \\
\hline 17. & Tapanuli Selatan & 68,4 \\
\hline 18. & Mandailing Natal & 67,5 \\
\hline 19. & Nias & 66,1 \\
\hline
\end{tabular}

Source: Statistics Indonesia (2012)

In Madailing Natal Regency, the Human Development Index (HDI) is still fluctuating or fluctuating in the lowest range of 67.50 percent, which is very unusual considering that Mandailing Natal is a capital area, following tables and graphs:

Table 2: Human Development Index (HDI) of Mandailing Natal Regency (MADINA) 2012

\begin{tabular}{|c|c|c|}
\hline No. & Year & Human Development Index (HDI) ( \% ) \\
\hline 1. & 2001 & 63,00 \\
\hline 2. & 2002 & 63,20 \\
\hline 3. & 2003 & 63,60 \\
\hline 4. & 2004 & 64,90 \\
\hline 5. & 2005 & 65,80 \\
\hline 6. & 2006 & 69,42 \\
\hline 7. & 2007 & 71,43 \\
\hline 8. & 2008 & 69,92 \\
\hline 9. & 2009 & 68,80 \\
\hline 10. & 2010 & 67,90 \\
\hline 11. & 2011 & 67,80 \\
\hline 12. & 2012 & 67,50 \\
\hline
\end{tabular}

Source: Statistics Indonesia (2012)

From Table 2. It can be seen in the graph that the HDI in Madina Regency is still fluctuating in the lowest range of an average of 67.50 percent. In the first Human Development Report in 1990, UNDP reminded that the main goal of development is human welfare (human welfare). This indicator is not only for per capita income but rather on the hope of collaboration of various parties, for example in this case the HDI. Alignment of local government budgets on the quality of human resources in HDI. It was 
also explained by the Forum Indonesia untuk Transparansi Anggaran (FITRA) that Madina was included in the 10 worst regional expenditures in the last 5 years, namely in 2012 it was threatened, because its personnel expenditure was above 54 percent, the Madina District Office was 33\% direct spending and 67\% indirect spending.

Efforts to measure the achievement of human development in an area must be able to provide certainty about the welfare of the population as well as the magnitude of the level of achievement of the ideal target at any time. The current policy is stipulated in Law No. 32 of 2004 concerning Regional Government which requires district governments to carry out "mandatory mandates", including to provide public services for the community which are also regulated in the 1945 Constitution. The budget is an official government statement regarding the estimated revenue and proposed expenditures in the current year and is a financial plan that reflects the government's policy choices, both social and economic policies (Khan and Hildreth 2002; Salihu, 2005; Shim and Siegel 2005). As a social and economic policy instrument, (Musgrave 1959), identified three budget functions.

Since the enactment of regional laws and regulations with the aim of balancing the central government in which the regional government shows unpreparedness here and there, the most visible contrast is the polemic of the emergence of the rule of new kings which only creates the deepest gap between the power of the apparatus and the welfare of the people. This example can be seen clearly if we look the regional finances in every district throughout Indonesia. Take a look at the research sample being researched below, namely Mandailing Natal Regency as below.

Table 3: The Realization of Regional Expenditure, Total Population, Number of Poor People and Proportion of QHR Madina Regency in 2012

\begin{tabular}{|c|c|c|c|c|c|}
\hline No. & Year & $\begin{array}{c}\text { Realization of } \\
\text { Government Budget } \\
\text { (Rp. Billion) }\end{array}$ & $\begin{array}{c}\text { Total } \\
\text { Population } \\
\text { (person) }\end{array}$ & $\begin{array}{c}\text { Total of Poor } \\
\text { Population } \\
\text { (60\%) }\end{array}$ & $\begin{array}{c}\text { Proportion of } \\
\text { QHR (percent) } \\
\text { (40\%) }\end{array}$ \\
\hline 1 & 2002 & 56,85 & 389.893 & 233.935 & 159.557 \\
\hline 2 & 2003 & 62,91 & 391.983 & 235.190 & 159.557 \\
\hline 3 & 2004 & 72,74 & 398.893 & 239.336 & 163.963 \\
\hline 4 & 2005 & 77,60 & 409.907 & 245.944 & 165.398 \\
\hline 5 & 2006 & 92,13 & 413.495 & 248.097 & 165.398 \\
\hline 6 & 2007 & 154,20 & 417.945 & 250.497 & 166.998 \\
\hline 7 & 2008 & 186,90 & 419.181 & 251.509 & 167.672 \\
\hline 8 & 2009 & 178,38 & 427.637 & 256.582 & 171.055 \\
\hline 9 & 2010 & 205,01 & 430.098 & 258.059 & 172.039 \\
\hline 10 & 2011 & 222,72 & 445.793 & 267.476 & 178.317 \\
\hline 11 & 2012 & 270,77 & 455.937 & 273.562 & 182.375 \\
\hline
\end{tabular}

Source: Statistics Indonesia (2012)

If we look at the sources in the table above regarding the realization of regional expenditure, the number of population, the number of poor people and the proportion of QHR Madina Regency 2012 above, the balance funds that are regulated by the government do not mean anything to autonomous regions, therefore the enthusiasm it 
is the regions that should increase regional revenues with the ability of QHR to its maximum.

\section{RESEARCH METHOD}

This research was conducted in Mandailing Natal Regency within the scope of analysis of the influence of the number of quality people, development budget, PDRBHK and structural transformation expenditure on the Human Development Index in Mandailing Natal Regency. The data to be processed and analyzed in this study is secondary data in the form of time series data for the period 2002 to 2012. This data comes from agencies or institutions related to the problems studied, including: Regional Revenue Service, Financial Management and Asset Regions, BPS, Mining Service and other agencies. To see the effect between the independent variable and the dependent variable, data interpolation was carried out per quarter during the 2003: Q1 - 2012: Q4 period. Thus the analysis carried out is an analysis using the Ordinary Least Square (OLS) model, (Tambunan, 2000) the data in the appendix. For independent variables that affect the dependent variable using the research model, Senhadji and Montenegro (1999) in Insukindro, namely with the formula:

$$
\begin{aligned}
& Y_{1}=1 / 4\left\{Y_{t}+\left(-4,5 / 12<Y_{t}-Y_{t-1}>\right)\right\} \\
& Y_{2}=1 / 4\left\{Y_{t}+\left(-1,5 / 12<Y_{t}-Y_{t-1}>\right)\right\} \\
& Y_{3}=1 / 4\left\{Y_{t}+\left(1,5 / 12<Y_{t}-Y_{t-1}>\right)\right\} \\
& Y_{4}=1 / 4\left\{Y_{t}+\left(4,5 / 12<Y_{t}-Y_{t-1}>\right)\right\}
\end{aligned}
$$

Where :

$Y_{1}=$ value of the first quarter $Y_{4}=$ value of the fourth quarter

$\mathrm{Y}_{2}=$ Value of the second quarter $\quad \mathrm{Y}_{\mathrm{t}}=$ Value in the calculated year

$\mathrm{Y}_{3}=$ Value of the third quarter $\quad \mathrm{Y}_{\mathrm{t}-1}=$ Value in the previous year

From the formula above, it is connected with reduce form for the variable under study to be

$$
H D I=f\{T Q H R, I P C, G B, G R D P C P, B M T S\}
$$

Then it is transformed into an equation model, namely:

$$
H D I=a_{0}+a_{1} \text { TQHRy }+a_{2} I P C y+a_{3} \text { GBy }+a_{4} \text { GRDPCPy }+a_{5} \text { BMTSy }+\varepsilon_{t} \ldots . . .
$$

Where :

$\begin{array}{ll}\mathrm{HDI} & =\text { Human Development Indeks (Indeks) } \\ \mathrm{TQHR} & =\text { Total of Quality of Human Resource (person) } \\ \mathrm{IPC} & =\text { Income Per Capita (Rupiah) } \\ \mathrm{GB} & =\text { Government Budget (Rupiah) } \\ \mathrm{GRDPCP} & =\text { Gross Regional Domestic Product at Constant Prices } \\ \mathrm{t} & =\text { Current Year } \\ \varepsilon_{\mathrm{t}} & =\text { Error Term } \\ \mathrm{a}_{0}-\mathrm{a}_{5} & =\text { Regression coefficient }\end{array}$




\section{RESULT AND DISCUSSION}

\section{Research Model Estimation Results}

The model estimation in this study uses the Eviews 4.0 software with the OLS method to see Human Development Index Model (HDI) where, total of quality people (TQHR), income per capita (IPC), Government Budget (GB) and GRDPCP against the Human Development Index in Mandailing Natal Regency. From the results of the estimation of the research model, the economic analysis, statistical analysis and econometric analysis will be tested with a model that is carried out by estimating the Barganda Linear Regression (OLS) equation. The discussion of this analysis is based on data that has been officially published which is formed and has been stated in the theoretical review and specification of the analysis model, then an economic analysis will also be carried out which explains the meaning of the parameters obtained from the linear regression equation that has been carried out, then see whether These parameters are compatible with economic theory. Likewise, analyzing the meaning of the coefficient value and the effect of changes in the independent variable on the dependent variable.

In this study, the regression estimation results for the HDI function are as shown in the results below

Table 4: Estimated Human Development Index (HDI)

Dependent Variable: LOG(IPM)

Method: Least Squares

Date: 10/18/13 Time: 22:12

Sample: 2003:1 2012:4

Included observations: 40

\begin{tabular}{lllll}
\hline \hline Variable & Coefficient & Std. Error & t-Statistic & Prob. \\
\hline \hline C & -7.834402 & 1.412372 & -5.546982 & 0.0000 \\
LOG(JOB) & 0.293044 & 0.162521 & 1.803112 & 0.0800 \\
LOG(IPC) & -0.428073 & 0.069408 & -6.167469 & 0.0000 \\
LOG(ABP) & -0.050311 & 0.020409 & -2.465159 & 0.0187 \\
LOG(PDRBHK) & 0.551823 & 0.115384 & 4.782494 & 0.0000 \\
\hline \hline R-squared & 0.896743 & Mean dependent var & 2.851316 \\
Adjusted R-squared & 0.884943 & S.D. dependent var & 0.026710 \\
S.E. of regression & 0.009060 & Akaike info criterion & -6.453388 \\
Sum squared resid & 0.002873 & Schwarz criterion & -6.242278 \\
Log likelihood & 134.0678 & F-statistic & 75.99037 \\
Durbin-Watson stat & 0.315004 & Prob(F-statistic) & 0.000000 \\
\hline \hline
\end{tabular}

Source: Research Model Estimation Results, data is processed

The results of HDI regression analysis can be written in the Linear equation as follows:

$$
\begin{aligned}
\log (H D I)= & -7.8344020+0.293044 * \log (T Q H R)-0.428073 * \log (\text { IPC })- \\
& 0.050311 * \log (G B)+0.551823 * \log (\text { GRDPCP })
\end{aligned}
$$

The estimation results of the Human Development Index (HDI), the variable total of quality people (TQHR) has a positive and significant effect on the Human Development Index in Mandailing Natal Regency, for the variable income per capita (IPC) has a negative and significant effect on $\mathrm{HDI}$ at $\alpha=10$ percent, while the variable GB has a 
negative and significant effect on HDI at $\alpha=10$ percent, the GRDPCP variable has a positive and significant effect at $\alpha=10$ percent on the Human Development Index (HDI) in Mandailing Natal Regency.

\section{Statistical t test (partial test)}

The t test or partial test is done to see the effect of the independent variable on the dependent variable partially or one by one. From the results of the estimation model for the Human Development Index (HDI), the t value for each variable is obtained as follows:

1. $\mathrm{JOB}$ in the Human Development Index (HDI) tstatistic value $=1.803$ with a probability level of 0.08 . This shows that the probability value is greater than $\alpha=$ 0.10 , so that TQHR variable is significant at the level of confidence of $90 \%$. It also has a positive effect on HDI. This means that if there is an increase in the JOB variable by 1 percent, there will be an increase in the Human Development Index (HDI) of 0.29 percent. Conversely, if there is a decrease in the JOB variable by 1 percent, the HDI will decrease by 0.29 percent.

2. IPC in the Human Development Index (HDI) tstatistic value $=-6.167$ with a probability level of 0.000 . This shows that the probability value is smaller than $\alpha$ $=0.10$, so that the IPC variable is significant at the level of confidence of $90 \%$, and has a negative effect on HDI. This means that if there is an increase in the IPC variable by 1 percent, there will be a decrease in the Human Development Index (IPM) of 0.42 percent. Conversely, if there is a decrease in the IPC variable by 1 percent, the HDI will increase by 0.42 percent.

3. $\mathrm{GB}$ in the Human Development Index (HDI) tstatistic value $=-2.465$ with a probability level of 0.01 . This shows that the probability value is greater than $\alpha=$ 0.10 , so that the ABP variable significantly affects the Human Development Index (HDI). This means that if there is an increase in GB variable by 1 percent, there will be a decrease in the Human Development Index (HDI) of 0.05. percent. Conversely, if there is a decrease in the ABP variable by 1 percent, the HDI will increase by 0.42 percent.

4. GRDPCP in the Human Development Index (HDI) tstatistic value $=4.782$ with a probability level of 0.000 . This shows that the probability value is smaller than $\alpha$ $=0.10$, so that GRDPCP variable is significant at the level of confidence of $90 \%$ and has a positive effect on the Human Development Index (HDI). This means that if there is an increase in the GRDPCP variable by $1 \%$, there will be an increase in the Human Development Index (IPM) of 0.55 percent in Mandailing Natal Regency. Conversely, if there is a decrease in GRDPCP variable by $1 \%$, it will reduce the Human Development Index (HDI) by 0.55 percent.

\section{F test statistic (Simultaneous Test)}

The F-test or the draw test is carried out to see the effect of the independent variables in the aggregate or together on the dependent variable. From the results of the estimation model for the Human Development Index (HDI), the F statistical value is 75.99037 with a probability level of 0.000 . This shows that the independent variables for the Human Development Index (HDI), namely TQHR, IPC, GB and GRDPCP

$$
\text { QE Journal | Vol.09 - No.02 - } 7
$$


simultaneously and significantly influence the dependent variable, namely $\mathrm{HDI}$ at the level of confidence level of $90 \%$.

\section{Determination Coefficient Test $\left(\mathbf{R}^{2}\right)$}

The coefficient of determination $\left(R^{2}\right)$ test is used to see how much variation in the independent variable can explain the dependent variable. From the estimation results for the Human Development Index (HDI), the R2 value is 0.896 . This means that $89.6 \%$ of the Human Development Index variable can be explained by TQHR, IPC, GB and GRDPCP variables. While the remaining $10.4 \%$ is explained by other variables outside the model.

\section{Economic Interpretation}

From the estimation results of the Human Development Index, it is obtained:

1. The regression coefficient for total of quality of human resources (TQHR) is 0.293, which means that if there is an increase in the number of qualified people by 1 percent, the Human Development Index will increase by 0.29 percent. The results of this study are inconsistent with research conducted by Bank Indonesia Medan with the Coordinator of the Expert Group for the Governor of North Sumatra and Statistics Indonesia of North Sumatera (2003), with the title Research on the Impact of Development Expenditures on Economic Growth, Development Index and Number of Quality Populations in Regencies / Cities in North Sumatera. in his research concluded that per capita development spending in 2002 has a positive effect, while 2003 has a negative effect on economic growth which is not significant, the effect is on the error rate (error) $\alpha$ = 5 percent or 10 percent. Furthermore, per capita development spending per year 2002 and 2003 had a positive influence on the Human Development Index. The results do not match the above, meaning first the original regional BPS report while the BPS-SU and Central reports are full of engineering, secondly negative economic growth is due to the transformation of capital disappearing by the power of office.

2. The income per capita regression coefficient (IPC) is -0.428 , which means that if there is an increase in IPC by 1 percent, the Human Development Index will decrease by 0.43 percent, and vice versa. The results of this study are not in accordance with the theory and hypothesis which states that if the individual income or income per capita increases, the HDI will increase. The results show that the income received by the residents of Mandailing Natal district is mostly spent on food consumption, or even the income received by some of the population is still below the standard of meeting their decent living needs. This was indicated by the existence of Raskin, temporary BLT and BSM.

3. The government budget regression coefficient (GB) is -0.050 , which means that if there is an increase in GB by $1 \%$ it will reduce the Human Development Index by 0.05 percent, and vice versa. This result is not in accordance with the theory and previous research, namely that the government budget has a positive and significant effect on HDI. This is because the budget issued by the Mandailing

$$
\text { QE Journal | Vol.09 - No.02 - } 8
$$


Natal district government is still not pro human, meaning that the expenditure budget is only used up for consumption of employee salaries, spending for official needs only. So that the expenditure budget that is used for the benefit of the community is only a small part. The results of this study indicate that the budget proclaimed by the Mandailing Natal district government is not promiddle-low. These results are also consistent with research by Utami, (2005), Socio-Economic Impacts and Evaluation of Regional Expenditures and Development Projects (case study: Education and Health Sector in North Sumatra Province), where it can be concluded that a large part of government development spending not yet pro-human in nature. Official projects are not on target.

4. he regression coefficient of GRDPCP is 0.551823 , which means that if there is an increase in GRDPCP of $1 \%$ it will increase the Human Development Index by 0.55 percent, vice versa. The results of this study are in line with previous research by Bank Indonesia Medan with the Coordinator of the Expert Group of the Governor of North Sumatra and Statistics Indonesia of North Sumatra (2003), with the title Research on the Impact of Development Expenditures on Economic Growth, Development Index and Number of Quality Population in Regencies / Cities throughout North Sumatra, in His research concluded that per capita development spending in 2002 had a positive effect, while 2003 had a negative effect on economic growth which was not significant, the effect was on the error rate $\alpha=5$ percent or 10 percent. Furthermore, per capita development spending per year 2002 and 2003 had a positive influence on the Human Development Index. For the calculations of the LPJ with the DPRD it is sufficient as a budget per year but negative / insignificant because every project in the local government service occurs irregularities by a person in the position of aji mumpung, meaning that while holding a position of corruption as much as possible, the term of office is haunted by two categories, namely:

a. Position tendered.

b. Mutation threat category.

Deviation of official projects and cooperation with black conglomerates is a disease, treating it with the only way is to improve the HDI indicator called MYS must be increased by strict supervision on Structural Transformation Capital Expenditures (BMTS) so as not to be minus as seen in the following estimation according to Eviews, if there is multicollinearity, the steps are:

1. Adding independent variables

2. Reducing independent variables

3. Create policy variables

From Evews' suggestion above, for my research, I took steps 2 and 3, namely by replacing the IPC variable (because the problem of this variable is negative and significant is a matter of policy, namely the concern factor by black apparatus and conglomerates) with BTS, thus IPC becomes positive and significant. The impact of this BTS insert is that GB will be positive and significant with the hope that BTS will also be 
positive if the apparatus and conglomerates care about equal distribution of income or what is certain is that the apparatus and conglomerates must total of quality of human resources (THQR) in Madina.

Table 5: Estimated Human Development Index (HDI) (variable IPC is replaced with BTS) Dependent Variable: LOG(IPM)

Method: Least Squares

Date: 12/11/13 Time: 19:52

Sample: 2003Q1 2012Q4

Included observations: 40

\begin{tabular}{lllll}
\hline \hline Variable & Coefficient & Std. Error & t-Statistic & Prob. \\
\hline \hline C & -8.866634 & 1.641423 & -5.401795 & 0.0000 \\
LOG(JOB) & 0.357333 & 0.167545 & 2.132756 & 0.0400 \\
LOG(ABP) & 0.032216 & 0.014277 & 2.256447 & 0.0304 \\
LOG(PDRBHK) & 0.394504 & 0.099375 & 3.969840 & 0.0003 \\
LOG(BTS) & -0.141452 & 0.024238 & -5.836021 & 0.0000 \\
\hline \hline R-squared & 0.890795 & Mean dependent var & 2.851316 \\
Adjusted R-squared & 0.878314 & S.D. dependent var & 0.026710 \\
S.E. of regression & 0.009318 & Akaike info criterion & -6.397376 \\
Sum squared resid & 0.003039 & Schwarz criterion & -6.186266 \\
Log likelihood & 132.9475 & F-statistic & 71.37437 \\
Durbin-Watson stat & 0.429339 & Prob(F-statistic) & 0.000000 \\
\hline \hline
\end{tabular}

Source: Research Model Estimation Results, data is processed

The results of the HDI regression analysis after the IPC variable were replaced with the BTS variable, the Linear equation was as follows:

\section{$\log (\mathrm{HDI})=-8.866634+$ \\ $0.357333 * \log (T Q H R)+0.032216 * \log (G B)+0.394504 * \log (G R D P C P)-$ \\ $0.141452 * \log (B T S)$}

The estimation results on the Human Development Index (HDI), namely; the variable number of qualified people (JOB) has a positive and significant effect at the level of $\alpha=$ 5 percent of Mandailing Natal Regency, variable GB has a positive and significant effect on $\alpha=5$ percent, GRDPCP variable has a positive and significant effect. at $\alpha=5$ percent. Meanwhile, the structural transformation spending variable (BTS) has a negative and significant effect on $\mathrm{HDI}$ at $\alpha=10$ percent in Mandailing Natal Regency.

\section{CONCLUSIONS AND RECOMMENDATIONS}

\section{Conclusion}

1. In the analysis of the influence of the number of qualified people on total of quality of human resources (TQHR) of Mandailing Natal Regency, it is concluded that total of quality of human resources (TQHR) has a positive and significant effect on the HDI of Mandailing Natal Regency.

2. In the analysis of the effect of the variable income per capita (IPC) on the Human Development Index (HDI), it is concluded that it has a negative and significant relationship with the Human Development Index (HDI) in Mandailing Natal Regency, but this relationship can be positive and significant if structural

QE Journal | Vol.09 - No.02 - 10 
transformation is implemented properly. ; for example the budget should not be distorted or run straight.

3. In the analysis of the influence of the government development expenditure budget (GB) on the Human Development Index (HDI), has a negative and significant relationship with the Human Development Index in Mandailing Natal Regency, this can be positive if the expenditure budget is used on target.

4. In the analysis of the effect of PDRBHK on the Human Development Index, it can be concluded that GRDPCP has a positive and significant effect on HDI in Mandailing Natal Regency.

\section{Suggestion}

1. To improve the quality of human development, the government should increase the number of qualified people in the Mandailing Natal district by improving the quality and quality of infrastructure, education, health and access for the community to increase per capita income.

2. Government budget policy should be based on a pro human budget, so that the quality of human resources reflected in HDI will increase. The increase in HDI will increase the income per capita in turn will increase economic growth. .

3. Local governments should improve the quality of human resources through education, health, per capita income, structural transformation and training simultaneously and encourage any policies that seek to improve these human resources. Increasing the quality of human resources will increase growth and development.

4. Local governments should improve the regional economy by looking for new and creative sources of regional income so that they can become new sources of income in improving the regional economy, for example the agricultural, plantation, mining, tourism, etc. Increasing the regional economy will automatically increase the GRDP.

\section{REFERENCES}

Azril.2000."Pembangunan Sumber Daya Manusia dan Indeks Pembangunan Manusia di Indonesia. Jurnal dan Bisnis Indonesia. Vol. 15 No. 1, 2000:1-14

Abimayu, Anggito. 2005. Format Anggaran Terpadu Menghilangngkan Tumpang Tindih. Bappeki Depkeu.

Arti Dyah Worotami.2005.Dampak Sosial Ekonomi dan Evaluasi Belanja Daerah, Proyek Pembangunan (Studi Kasus: Bidang Pendidikan dan Kesehatan di Provinsi Sumatera Utara, Departemen Dalam Negeri, www.depdagri: go.id

BPS. 2012. Laporan Keuangan Mandailing Natal, BPS Madina.

----- 2012. Indeks Pembangunan Manusia Kabupaten Madina. BPS Sumut

Bank Indonesia Medan dengan Koordinator Kelompok Ahli Gubernur Sumatera Utara dan BPS - SU .2003, Dampak Belanja Pembangunan Terhadap Pertumbuhan 
Ekonomi; Indeks Pembangunan dan Jumlah Penduduk Miskin di Kabupaten Kota seSumatera Utara, BI Cabang Medan. www.bi:id

Bratakusumah, RDS. 2005, Perencanaan Pembangunan Daerah, Strategi Menggali Potensi dalam Mewujudkan Otonomi Daerah. Penerbit PT. Gramedia Pustaka Utama, Jakarta.

Chenery, Hills B., and Moshe Syrquind(1975). Paterns and Development, 1950-1970. Oxford University Pers, London.

Chenery, Hills B., Shisindo, Shuntaro and Wanatabe, Tshunehiko." The Paternt Japanise Grouth 1914- 1954."Ekonometrika January 1962,30 (I) hal 98-137.

Clark, Nasution. 1991. Aspek Penting Belanja Transformasi Struktural

Darise, Nurlan, 2007. Pengelolaan Keuangan Pada Satuan Kerja Prangkat Daerah (SKPD), Penerbit Indeks, Jakarta.

Delavallade, Clara.2006. "Coruption and Distribution of Publik Spending in Developing Countries". Journal Ekonomi and Finance. Vol. 30. No. 2: 222-239.

Fery, Adrianus.2002."Analisis Pengeluaran Pendidikan dan Pertumbuhan Ekonomi di Indonesia. Jurnal Ekonomi, Manajemen dan Akuntansi. Vol. 1. No. 2, Mei 2002:113-119.

Gujarati, Domar. 1995. Ekonomi Dasar. Erlangga, Jakarta.

Ghalib, Rush, 2005. Ekonommi Regional, Pustaka Ramadhan, Bandung.

Hill, Hall. Transformasi Ekonomi Indonesia sejak 1966: Sebuah Studi Kritis dan Komprehensif, Yogyakarta: PAU (Studi Ekonomi) UGM bekerja sama dengan PT. Tiara Wacana 1996.

Hyde. 1992. Anggaran bersifat Politik

Khan dan Hildreth. 2002. Kebijakan Sosial Ekonomi,

Kunchoro, Mudrajat. 2004. Otonomi dan Pembangunan Daerah (Reformasi Perencanaan, Strategi, dan Peluang. Penerbit Erlangga, Jakarta.

Lipton dan Vyas. 1981. Terjadinya Urban Bias

Mangkusoebroeto, Guritno, 2001, Ekonomi Publik, Penerbit BPFE-Yogyakarta.

Manurung.JJ; Manurung, H.A, Saragih, E.F.; 2005. Ekonometrika; Tiori dan Aplikasi. PT. Alex Media Komputindo.

Mardiasmo, Prof. 2004, Otonomi dan Managemen Keuangan Daerah, Penerbit Andi Yogyakarta.

Murbanto,Sinaga. 2006, Suatu Tinjauan Kebijakan Alokasi Belanja Tiga Bidang Utama (Sosial, Budaya, Infrastruktur Ekonomi) RAPBP TA.2006 Provinsi Sumatera Utara, tesis, Medan, USU.

Musgrave. 1959. Tiga Fungsi Anggaran

QE Journal |Vol.09 - No.02 - 12 
Noeroso, I. Wahyudi, Dampak Sosial Ekonomi dan Evaluasi Belanja Daerah dan Proyek Pembangunan Studi Kasus; Sektor Pendidikan, Departemen Dalam Negeri. www. Depdagri.go.id.

Nasution. 1991. Widya Karya Gizi.

Siagian, Bukit Buchori, 2009. Analisis Keberpihakan Anggaran Belanja Pembangunan Kabupaten Asahan Terhadap Kelompok Masyarakat Miskin, tesis, Medan, Unimed.

Sahrah, Alimartus. 2007. Memberdayakan Sumberdaya Manusia Untuk Meningkatkan Kualitas Bangsa. Pidato Dies Natalis Unwama ke XXI, yogyakarta.

Salihu, Shim, Siegel. 2005. Instrumen Kebijakan Sosial dan Ekonomi

Syah . 2007. Membuat Anggaran yang lebih Baik. United Nation Capital Development Fund.

Todaro, Smith. 2006. Faktor kualitas Sumber Daya Manusia dalam Pertumbuhan Ekonommi. Report on the world social situation, ejournal, Undip. 